\title{
KARAKTERISASI DAN APLIKASI ENZIM TRANSGLUTAMINASE DARI Streptoverticillium ladakanum PADA DAGING LUMAT IKAN MATA GOYANG
}

\author{
Yusro Nuri Fawzya*), Dewi Seswita Zilda*), Achmad Poernomo*), Indra Kristiana**, dan \\ Happy Nursyam ${ }^{\star * * *}$
}

\begin{abstract}
ABSTRAK
Telah dilakukan karakterisasi enzim transglutaminase mikroba (MTGase) yang diproduksi dari Streptoverticillium ladakanum dengan menggunakan media yang mengandung limbah cair tahu dan hidrolisat tepung tapioka. Enzim MTGase yang dikarakterisasi merupakan enzim kasar yang telah dipekatkan menggunakan ultrafiltrasi dan dikeringbekukan. Enzim ini kemudian diaplikasikan pada daging lumat ikan mata goyang (Priacanthus macracanthus) lalu diamati sifat fisik (tekstur) produk restrukturisasi yang dihasilkan. Sebagai pembanding, dilakukan aplikasi TGase komersial (KTGase) pada daging lumat yang sama. Penambahan TGase dilakukan dengan 2 cara, yaitu: (1) bersama-sama dengan garam $\mathrm{NaCl} 1 \%$, (2) bersama-sama dengan garam $\mathrm{NaCl} 1 \%$ dan sodium kaseinat $1 \%$. Sebagai kontrol adalah daging lumat ditambah garam $\mathrm{NaCl}$ 1\% (tanpa penambahan enzim TGase). Hasil penelitian menunjukkan bahwa MTGase dari $S$. ladakanum bekerja optimum pada $\mathrm{pH} 8$ dan suhu $55^{\circ} \mathrm{C}$. Aktivitas enzim ini relatif tidak terpengaruh oleh adanya ion logam $\mathrm{Ca}^{2+}, \mathrm{Mg}^{2+}, \mathrm{Na}^{+}$, dan $\mathrm{K}^{+}$maupun inhibitor seperti ethylenediaminetetraacetic acid (EDTA), dan phenylmethylsulfonylfluoride (PMSF). Enzim MTGase tanpa penambahan sodium kaseinat menunjukkan kemampuan membentuk gel yang tidak berbeda dengan TGase komersial, menghasilkan kekuatan gel $16848 \mathrm{~g} \mathrm{~mm}$ dan nilai kekenyalan 0,97. Enzim ini juga terbukti dapat meningkatkan kekuatan gel, kekenyalan, dan kepadatan produk restrukturisasi daging lumat ikan yang hanya ditambah garam $\mathrm{NaCl}$ saja atau yang ditambah garam $\mathrm{NaCl}$ dan sodium kaseinat.
\end{abstract}

KATAKUNCl: $\quad$ transglutaminase, Streptoverticillium ladakanum, karakterisasi, aplikasi

ABSTRACT: Characterization and application of transglutaminase produced by Streptoverticillium ladakanum on the Priacanthus macracanthus minced meat. By: Yusro Nuri Fawzya, Dewi Seswita Zilda, Achmad Poernomo, Indra Kristiana and Happy Nursyam

Characterization of microbial transglutaminase (MTGase) produced by Streptoverticillium ladakanum using medium containing tofu liquid waste and tapioca hydrolisate has been conducted. The characterized enzyme was crude enzyme which has been concentrated by ultrafiltration followed by freeze drying. This MTGase was then applied to minced meat of Priacanthus macracanthus and the physical property (texture) of restructured fish was observed. As comparison, application of commercial TGase (KTGase) was carried out simultaneously. The addition of TGase was conducted by 2 methods: (1) mixed with $1 \% \mathrm{NaCl}$ and (2) mixed with $1 \% \mathrm{NaCl}$ and $1 \%$ sodium caseinate. Minced fish which added with $1 \% \mathrm{NaCl}$ without TGase was used as control. The result showed that MTGase produced from S. ladakanum worked optimally at $\mathrm{pH} 8$ and temperature of $55^{\circ} \mathrm{C}$. The enzyme activity was not relatively affected by metal ions of $\mathrm{Ca}^{2+}, \mathrm{Mg}^{2+}, \mathrm{Na}^{+}$and $\mathrm{K}^{+}$, as well as inhibitors such as ethylenediaminetetraacetic acid (EDTA) and phenylmethylsulfonylfluoride (PMSF). The enzyme showed that gel forming ability was as good as the commercial TGase. Without addition of sodium caseinate, this enzyme produced gel strength of $16848 \mathrm{~g} \mathrm{~mm}$ and elasticity of 0.97 . This enzyme was also able to increase the gel strength, springiness and cohesiveness of restructured fish produced by the addition of $1 \% \mathrm{NaCl}$ (control) or mixture of $1 \%$ $\mathrm{NaCl}$ and $1 \%$ sodium caseinate.

KEYWORDS: transglutaminase, Streptoverticillium ladakanum, characterization, application

7 Peneliti pada Balai Besar Penelitian dan Pengembangan Pengolahan Produk dan Bioteknologi Kelautan dan Perikanan, Balitbang KP, KKP; JI. KS. Tubun Petamburan VI, Jakarta Pusat; E-mail: nuri_fawzya@yahoo.com

*) Badan Penelitian dan Pengembangan Kelautan dan Perikanan; JI. Pasir Putih I, Ancol Timur, Jakarta Utara

Alumni Program Studi Bioteknologi, Sekolah Pasca Sarjana, Universitas Brawijaya; Jl. Mayjen Haryono 169, Lowokwaru, Malang, Jawa Timur

Staf Pengajar Program Studi Bioteknologi, Sekolah Pasca Sarjana,Universitas Brawijaya; JI. Mayjen Haryono 169, Lowokwaru, Malang, Jawa Timur 


\section{PENDAHULUAN}

Transglutaminase (TGase) merupakan enzim yang termasuk dalam kelompok transferase, memiliki peran yang sangat penting dalam pembentukan gel dan elastisitas produk berbahan dasar daging lumat dan surimi. Enzim ini mengkatalisis polimerisasi dan membentuk ikatan silang (crosslinking) $\varepsilon$-( $(\gamma$-glutamyl)lisin antara residu glutamin $(G \mid n)$ dan lisin (Lys) pada protein bahan pangan (Motoki \& Seguro, 1998). Salah satu sumber penghasil enzim TGase adalah mikroorganisme; enzim yang dihasilkan biasa disebut transglutaminase mikroba (MTGase), umumnya berasal dari kelompok Actinomycetes, yaitu dari genus Streptoverticillium atau Streptomyces.

Aplikasi transglutaminase pada daging ikan telah banyak dilaporkan, di antaranya adalah mengenai aplikasi TGase yang diproduksi dari S. ladakanum menggunakan media yang mengandung hidrolisat jerami sorgum pada daging ikan Mexican flounder (Cyclopsetta chitenndenni) (Tellez-Luiz et al., 2004), aplikasi TGase mikroba pada ikan mas (Vacha et al., 2006), aplikasi TGase pada pembuatan bakso kaleng menggunakan surimi ikan threadfin bream (Runglerdkriangkrai et al., 2006), penggunaan enzim TGase komersial (Activa TG-B) pada ikan white croacker (Micropogonias furnieri) (Gonçalves \& Passos, 2010), pengaruh garam dan TGase komersial pada daging lumat ikan mata goyang (Fawzya et al., 2011ㄹ) dan pengaruh TGase pada ikan tongkol (Fawzya et al., 2011 ${ }^{\mathrm{b}}$ ).

Meskipun enzim ini telah diproduksi secara komersial, namun penelitian yang berkaitan dengan penapisan mikroba penghasil TGase, medium produksi dan aplikasi TGase masih banyak dilakukan guna mendapatkan keunggulan tertentu. Medium produksi enzim MTGase umumnya mengandung ekstrak khamir, pepton, dan sodium kaseinat sebagai nutrisi bagi mikroorganisme penghasilnya, namun modifikasi telah banyak dilaporkan untuk meningkatkan aktivitas enzim yang dihasilkan di samping untuk mendapatkan komponen media yang lebih murah, seperti penggunaan hidrolisat jerami sorgum (Tellez-Luiz et al., 2004), molase, maltodekstrin, soluble starch, tepung kedelai, corn steep liquor (Macedo et al., 2007), limbah cair surimi (Ridwan, 2010), limbah cair tahu, dan hidrolisat tepung tapioka (Zilda et al., 2011).

Penelitian ini melanjutkan penelitian yang dilakukan oleh Zilda et al. (2011) yang menitikberatkan pada optimasi medium produksi menggunakan limbah cair tahu sebagai sumber nitrogen dan hidrolisat tapioka sebagai sumber karbon. Tujuan penelitian adalah melakukan karakterisasi transglutaminase yang diproduksi menggunakan media hasil optimasi tersebut kemudian mengaplikasikannya pada daging lumat ikan dibandingkan dengan transglutaminase komersial.

\section{BAHAN DAN METODE}

Enzim transglutaminase yang digunakan pada penelitian ini diproduksi dari Streptoverticillium ladakanum NRL 3191 yang diperoleh dari Agricultural Research Service, United State Department of Agricultural. Sebagai medium produksi digunakan formula hasil optimasi Zilda et al. (2011) yang mengandung limbah cair tahu dari pabrik pembuatan tahu di Palmerah, Jakarta Barat dan hidrolisat tepung tapioka. Tepung tapioka yang digunakan merk Gunung Agung dari PT. Budi Acid Jaya, Tbk. Sungai Budi Grup Lampung. Tepung tapioka ini dihidrolisis menggunakan enzim amilase dari Balai Besar Penelitian Pascapanen Pertanian Bogor. Aplikasi TGase dilakukan pada daging lumat ikan mata goyang (Priacanthus macracanthus) yang diperoleh dari UKM filet ikan di TPI Pelabuhan Jonggol, Kabupaten Tegal. Filet dibawa dalam cool box yang sudah diisi es curah ke Laboratorium Pengolahan BBP4BKP.

Sebagai enzim pembanding digunakan enzim TGase komersial (Activa TG-BW-MH) dari PT. Ajinomoto yang mengandung sodium kaseinat, maltodekstrin, TGase, dan sodium klorida. Bahan lain yang digunakan adalah bahan kimia/media yang meliputi bahan untuk produksi enzim yaitu ekstrak khamir (Oxoid); pepton (Oxoid); $\mathrm{MgSO}_{4}$ (Merck); $\mathrm{KH}_{2} \mathrm{PO}_{4}$ (Merck); $\mathrm{Na}_{2} \mathrm{HPO}_{4}$ (Merck), bahan untuk karakterisasi enzim yaitu Tris- $\mathrm{HCl}$ buffer $\mathrm{pH} 6 ; \mathrm{FeCl}_{3}$ (Merck); EDTA; PMSF, bahan untuk uji aplikasi enzim yaitu sodium kaseinat dan garam serta bahan untuk pengujian aktivitas enzim yaitu hidroksilamin (SigmaAldrich); glutation (Sigma-Aldrich); N-CBZ-GLN-GLY (Sigma-Aldrich); Trichloroacetic acid (Merck).

\section{Produksi Enzim TGase (Zilda et al., 2011)}

Produksi diawali dengan pembuatan starter $S$. ladakanum menggunakan medium cair untuk starter yang komposisinya sama dengan medium produksi yaitu $41,42 \%$ limbah cair tahu; $0,46 \%$ hidrolisat tapioka; $0,17 \%$ ekstrak khamir; $1,22 \%$ pepton; $0,05 \%$ $\mathrm{MgSO}_{4} ; 0,2 \% \mathrm{KH}_{2} \mathrm{PO}_{4} ; 0,5 \% \mathrm{Na}_{2} \mathrm{HPO}_{4} ;$ dan akuades. Kemudian starter sebanyak $10 \%$ dari total media produksi ditambahkan ke dalam media produksi enzim: dan diinkubasi dalam inkubator goyang pada suhu $26^{\circ} \mathrm{C}$ dengan kecepatan agitasi $150 \mathrm{rpm}$ selama 72 jam. Setelah inkubasi, larutan disentrifus dengan kecepatan $8000 \mathrm{rpm}$, suhu $4^{\circ} \mathrm{C}$ selama 15 menit untuk memisahkan pelet dan supernatan. Supernatan sebagai ekstrak kasar enzim kemudian dipekatkan menggunakan ultrafiltrasi cut off $10.000 \mathrm{Da}$, dengan 
terlebih dahulu dilakukan penyaringan menggunakan kertas saring Whatman no. 42 (kertas saring $125 \mathrm{~mm}$ ), kemudian dikeringbekukan. Terhadap ekstrak kasar enzim, hasil pemekatan selanjutnya dilakukan pengujian aktivitas enzim (Grossowicz et al., 1950 dalam Ando, 1989) dan kadar protein terlarut dengan metode Lowry (Bollag \& Edelstein, 1991).

\section{Karakterisasi Enzim}

Terhadap filtrat MTGase hasil ultrafiltrasi dilakukan karakterisasi dalam hal penentuan $\mathrm{pH}$ optimum, suhu optimum, inhibitor dan aktifator. Untuk penentuan $\mathrm{pH}$ optimum enzim digunakan buffer asetat ( $\mathrm{pH} 4,5,6)$, buffer tris $\mathrm{HCl}(\mathrm{pH} 6,7,8)$, dan buffer borat $(\mathrm{pH} 8,9)$. Buffer ditambah dengan substrat dan pereaksi lainnya dalam reagen $\mathrm{A}$, kemudian direaksikan dengan enzim sesuai prosedur pengujian aktivitas enzim MTGase berdasarkan metode Grossowicz et al., 1950 dalam Ando,1989.

Penetapan suhu optimum dilakukan dengan menguji aktivitas enzim pada $\mathrm{pH}$ optimumnya, pada suhu $8^{\circ} \mathrm{C}$ (suhu refrigerator), $26^{\circ} \mathrm{C}$ (suhu ruang), $37^{\circ} \mathrm{C}$, $45^{\circ} \mathrm{C}, 55^{\circ} \mathrm{C}$, dan $65^{\circ} \mathrm{C}$. Pengaruh ion logam $\left(\mathrm{Ca}^{2+}\right.$; $\mathrm{Mg}^{2+}$; $\mathrm{Na}^{+}$; dan $\mathrm{K}^{+}$) dan larutan inhibitor dilakukan dengan menguji aktivitas enzim pada $\mathrm{pH}$ dan suhu optimum dengan penambahan $1 \mathrm{mM}$ ion logam atau $1 \mathrm{mM}$ inhibitor. Kontrol dibuat tanpa menambahkan larutan ion logam maupun inhibitor MTGase ke dalam larutan supernatan enzim dan reagen lainnya.

\section{Uji Aktivitas MTGase (Grossowicz et al., 1950 dalam Ando, 1989)}

Larutan enzim sebanyak $200 \mu \mathrm{L}$ direaksikan dengan reagen A yang terdiri dari $200 \mu \mathrm{L} 0,2 \mathrm{M}$ Tris$\mathrm{HCl}$ buffer $\mathrm{pH}$ 6; $100 \mu \mathrm{L} \mathrm{0,1M}$ hidroksilamin; $100 \mu \mathrm{L}$ $0.01 \mathrm{M}$ glutation; $5 \mathrm{mg}$ N-CBZ-GLN-GLY; $100 \mu \mathrm{L} \mathrm{0,2N}$ $\mathrm{NaOH}$ dan $20 \mu \mathrm{L} 0,1 \mathrm{~N} \mathrm{NaOH}$, kemudian diinkubasi pada suhu $37^{\circ} \mathrm{C}$ selama 10 menit. Reaksi dihentikan dengan penambahan reagen $\mathrm{B}$ yang terdiri dari $3 \mathrm{~N}$ $\mathrm{HCl} ; 12 \%$ TCA; dan $5 \% \mathrm{FeCl}_{3} \cdot 6 \mathrm{H}_{2} \mathrm{O}$. Selanjutnya, diukur absorbansinya dengan elisa reader pada panjang gelombang $530 \mathrm{~nm}$. Blanko dibuat dengan cara yang sama, namun penambahan enzim dilakukan setelah larutan direaksikan dengan reagen B. Satu unit aktivitas enzim MTGase didefinisikan sebagai jumlah enzim yang dibutuhkan untuk menghasilkan satu $\mu \mathrm{mol}$ hidroksamat per menit pada suhu $37^{\circ} \mathrm{C}$.

\section{Uji Aplikasi Enzim MTGase (Ramirez et al., 2006 dimodifikasi)}

Filet daging ikan mata goyang (Priacanthus macracanthus) dicuci menggunakan air dingin kemudian dilumatkan lalu dicuci sebanyak 2 kali dengan air dingin $(1-5)^{\circ} \mathrm{C}$ dengan perbandingan antara daging giling dan air 1:4 untuk menghilangkan darah dan kotoran yang tersisa. Selanjutnya dilakukan penyaringan dan pengepresan untuk mengurangi air. Daging lumat yang sudah dicuci dibagi menjadi 3 bagian (untuk 3 kali ulangan percobaan). Masingmasing bagian dibagi menjadi 6 perlakuan, yaitu (1) penambahan garam meja ( $\mathrm{NaCl}) 1 \%$ sebagai kontrol; (2) penambahan garam meja $(\mathrm{NaCl}) 1 \%$ dan TGase komersial (KTGase) $300 \mathrm{U} / \mathrm{kg}$ daging (setara dengan 4,48 g KTGase/kg daging dengan aktivitas $67 \mathrm{U} / \mathrm{g}$ enzim), (3) penambahan garam meja ( $\mathrm{NaCl}$ ) $1 \%$ dan MTGase $300 \mathrm{U} / \mathrm{kg}$ daging (setara dengan 9,8 g MTGase/kg daging dengan aktivitas 30,57 U/g enzim), (4) penambahan garam meja $(\mathrm{NaCl}) 1 \%$ dan $\mathrm{Na}$ kaseinat $1 \%$, (5) penambahan garam meja $(\mathrm{NaCl})$ $1 \%$, Na-kaseinat 1\%, dan TGase komersial (KTGase) $300 \mathrm{U} / \mathrm{kg}$ daging, (6) penambahan garam meja ( $\mathrm{NaCl}$ ) $1 \%$, Na-kaseinat $1 \%$, dan MTGase $300 \mathrm{U} / \mathrm{kg}$ daging. Daging lumat dari masing-masing perlakuan diaduk rata bersama-sama dengan garam $\mathrm{NaCl}$ selama 3-5 menit, sebelum penambahan bahan lainnya. Adonan daging dimasukkan ke dalam tabung plastik dan ditutup rapat, lalu dipanaskan pada suhu $\pm 40^{\circ} \mathrm{C}$ selama 1 jam untuk pengaktifan enzim dan pembentukan gel, kemudian dipanaskan pada suhu $\pm 90^{\circ} \mathrm{C}$ selama 15 menit diikuti dengan pendinginan segera dalam air es. Setelah dingin gel ikan dalam tabung disimpan semalam pada suhu $4^{\circ} \mathrm{C}$ dan diuji sifat-sifat tekstur dan elastisitasnya dengan menggunakan Texture Analyser (TA-XT). Uji aplikasi dilakukan 3 kali dengan desain percobaan menggunakan Rancangan Acak Lengkap sederhana. Data yang diperoleh dianalisis menggunakan one way ANOVA pada software Minitab 14. Secara garis besar uji aplikasi digambarkan pada diagram (Gambar 1).

\section{HASIL DAN BAHASAN}

\section{Pemekatan dan Karakterisasi Enzim}

Produksi MTGase dari S. ladakanum dengan menggunakan formula media yang mengacu pada Zilda et al. (2011) yang mengandung limbah cair tahu dan hidrolisat tapioka menghasilkan enzim dengan aktivitas $0,459 \mathrm{U} / \mathrm{mL}$. Setelah disaring kembali dengan kertas saring $125 \mathrm{~mm}$ dan dipekatkan menggunakan ultrafiltrasi cut off 10.000 Da aktivitas enzim meningkat berturut-turut menjadi $0,818 \mathrm{U} / \mathrm{mL}$ dan $3,319 \mathrm{U} / \mathrm{mL}$ (Tabel 1). Penyaringan enzim kasar sebelum pemekatan dimaksudkan untuk mempermudah proses pemekatan dengan ultrafiltrasi, karena enzim kasar yang dihasilkan memiliki konsistensi yang kental, diduga berkaitan dengan komponen media yang ada di dalamnya seperti hidrolisat tapioka. Tabel 


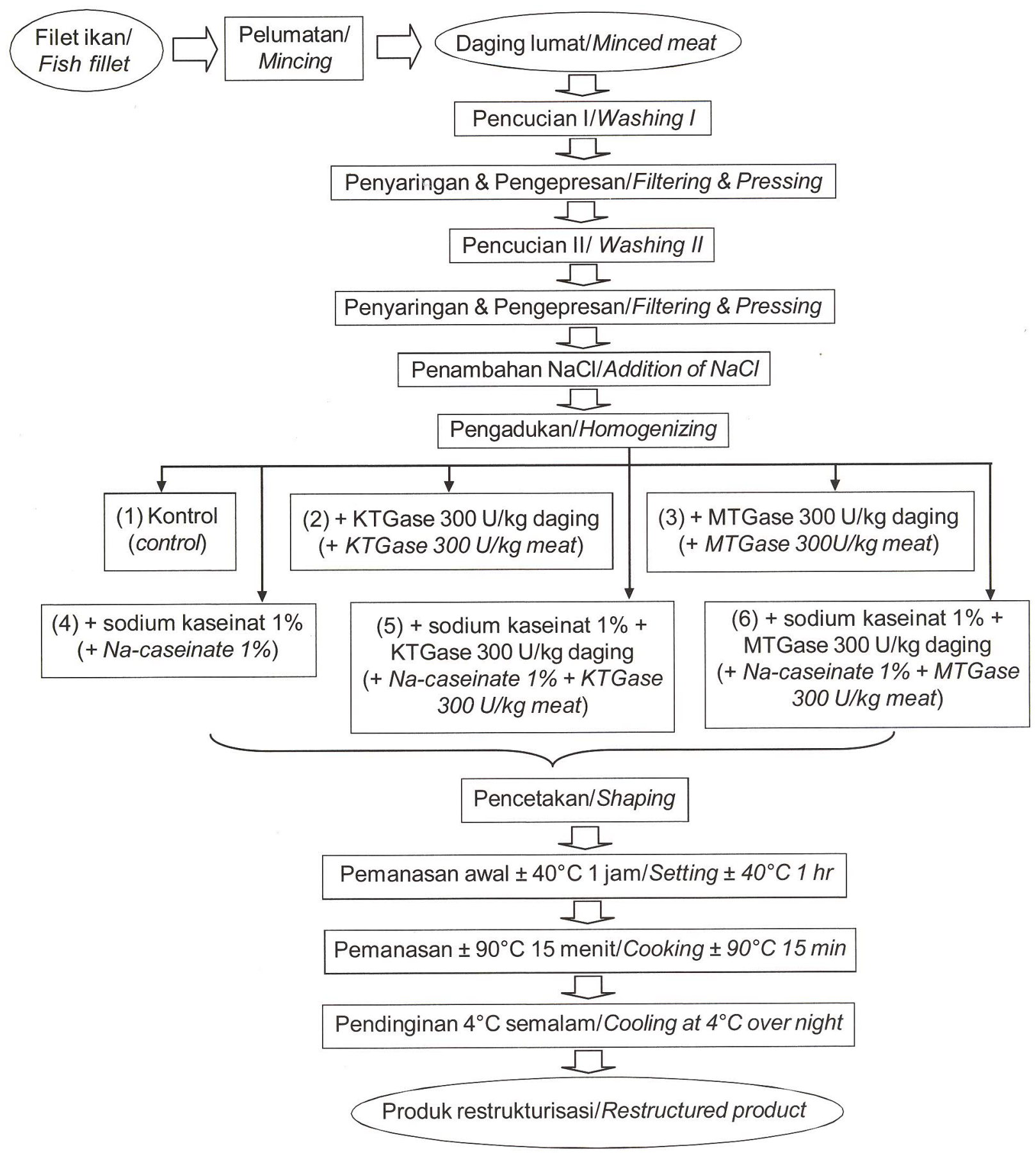

Gambar 1. Diagram alir uji aplikasi MTGase pada daging lumat ikan mata goyang.

Figure 1. Flow chart of MTGase application on minced Priacanthus macracanthus.

1 menunjukkan bahwa penyaringan dan pemekatan meningkatkan aktivitas enzim maupun aktivitas spesifiknya. Aktivitas spesifik enzim dipengaruhi oleh kadar protein, semakin tinggi aktivitas spesifik suatu enzim maka semakin tinggi kemurnian enzim tersebut. Hal ini menunjukkan terjadinya pemisahan protein lain yang bukan enzim (Mangunwidjaja \& Suryani, 1994).

Hasil karakterisasi terhadap MTGase menunjukkan bahwa enzim bekerja optimal pada buffer Tris $\mathrm{HCl} 0,2 \mathrm{M}$
pH 8 (Gambar 2) dan suhu $55^{\circ} \mathrm{C}$ (Gambar 3). Enzim MTGase yang memiliki pH optimum sekitar 8 juga ditemukan pada MTGase yang dihasilkan oleh spora bakteri Bacillus subtilis ( $\mathrm{pH}$ optimum 8,2) yang dilaporkan oleh Suzuki et al. (2000) dan TGase dari ikan nila (Oreochromis niloticus) dengan $\mathrm{pH}$ optimum 7-7,5 (Worratao \& Yongsawatdigul, 2005).

Seperti protein pada umumnya, kondisi lingkungan termasuk perubahan $\mathrm{pH}$ akan berpengaruh pada 
Tabel 1. Aktivitas MTGase sebelum dan setelah pemekatan

Table 1. MTGase activity before and after concentrating

\begin{tabular}{|c|c|c|c|c|c|}
\hline $\begin{array}{l}\text { Tahapan Pemekatan/ } \\
\text { Concentrating Steps }\end{array}$ & $\begin{array}{l}\text { Volume } \\
\qquad(\mathrm{mL})\end{array}$ & $\begin{array}{l}\text { Protein } \\
(\mathrm{mg} / \mathrm{mL})\end{array}$ & $\begin{array}{c}\text { Aktivitas } \\
\text { MTGase/ } \\
\text { MTGase } \\
\text { Activity } \\
\text { (U/mL) }\end{array}$ & $\begin{array}{c}\text { Total } \\
\text { Aktivitas/ } \\
\text { Total } \\
\text { Activity (U) }\end{array}$ & $\begin{array}{c}\text { Aktivitas } \\
\text { Spesifik/ } \\
\text { Specific } \\
\text { Activity } \\
(U / m g)\end{array}$ \\
\hline $\begin{array}{l}\text { Supernatan bebas sel (sebelum pemekatan)/ } \\
\text { Cell free supernatant (before concentrating) }\end{array}$ & 980 & 11.707 & 0.459 & 449.733 & 0.039 \\
\hline $\begin{array}{l}\text { Pemekatan dengan kertas saring } 125 \mathrm{~mm} / \\
\text { Concentrating using filter paper } 125 \mathrm{~mm}\end{array}$ & 960 & 10.381 & 0.818 & 7.85 .486 & 0.079 \\
\hline $\begin{array}{l}\text { Ultrafiltrasi (setelah pemekatan)/ } \\
\text { Ultrafiltration (after concentrating) }\end{array}$ & 100 & 13.276 & 3.319 & 331.910 & 0.250 \\
\hline \multicolumn{5}{|c|}{ Aktivitas MTGase setelah dikeringbekukan/MTGase activity after being freeze dried } & $30.57 \mathrm{U} / \mathrm{g}$ \\
\hline \multicolumn{5}{|c|}{ Aktivitas TGase komersial/Commercial TGase activity } & $67.00 \mathrm{U} / \mathrm{g}$ \\
\hline
\end{tabular}

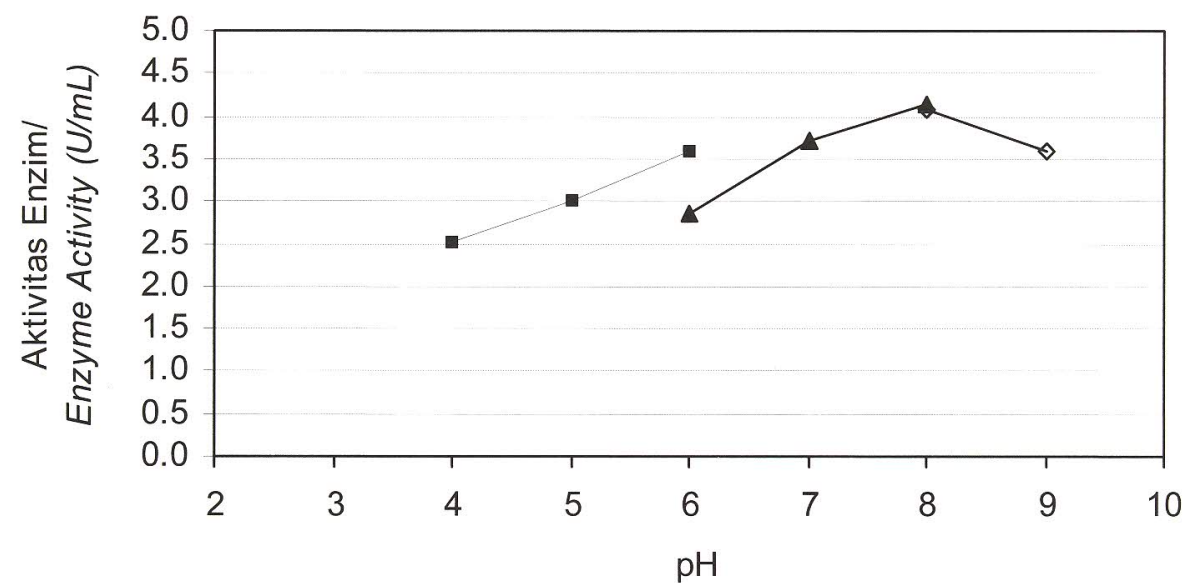

- Buffer Asetat 0,2 M0.2 M Acetic Buffer

—-Buffer Tris $\mathrm{HCl} 0,2 \mathrm{M} 0.2 \mathrm{M}$ Tris HCl Buffer

$\diamond$ Buffer Borat 0,2 W0.2 M Boric Buffer

Gambar 2. Pengaruh pH terhadap aktivitas MTGase dari S. ladakanum.

Figure 2. Effect of $\mathrm{pH}$ on the MTGase activity produced by S. ladakanum.

aktivitas bagian aktif enzim dalam membentuk kompleks enzim-substrat, karena muatan gugusgugus yang terdapat di dalam protein enzim, yaitu gugus karboksil dan asam amino, mengalami perubahan tingkat ionisasi. Pada $\mathrm{pH}$ yang optimum gugus pemberi dan penerima proton yang penting pada sisi katalitik enzim berada pada keadaan yang diinginkan sehingga aktivitas katalitiknya tinggi, dan enzim sangat efisien dalam mempercepat reaksi biokimia yang sangat spesifik. Sebaliknya, pada kondisi yang ekstrim seperti $\mathrm{pH}$ yang terlalu rendah atau tinggi, enzim dapat mengalami denaturasi yang akan mengakibatkan menurunnya aktivitas enzim (Poedjiadi, 1994).

Suhu optimum enzim MTGase umumnya berkisar antara $45^{\circ} \mathrm{C}$ sampai $55^{\circ} \mathrm{C}$ (Lin et al., 2008). Semakin tinggi suhu, energi kinetik molekul-molekul yang bereaksi semakin meningkat sehingga molekul yang bereaksi semakin banyak dan produk yang dihasilkan semakin besar. Namun apabila suhu terlalu tinggi, enzim dapat mengalami denaturasi dan perubahan konformasi struktur molekul enzim sehingga enzim kehilangan sifat alamiahnya dan aktivitasnya mengalami penurunan. Selain itu, substrat juga dapat mengalami perubahan konformasi sehingga gugus reaktifnya mengalami hambatan dalam memasuki sisi aktif enzim (Suhartono, 1989). Sedangkan pada suhu di bawah suhu optimum, aktivitas enzim juga rendah yang disebabkan oleh rendahnya energi aktivasi yang tersedia.

Karakter enzim MTGase lainnya menunjukkan bahwa keberadaan ion logam relatif tidak berpengaruh 


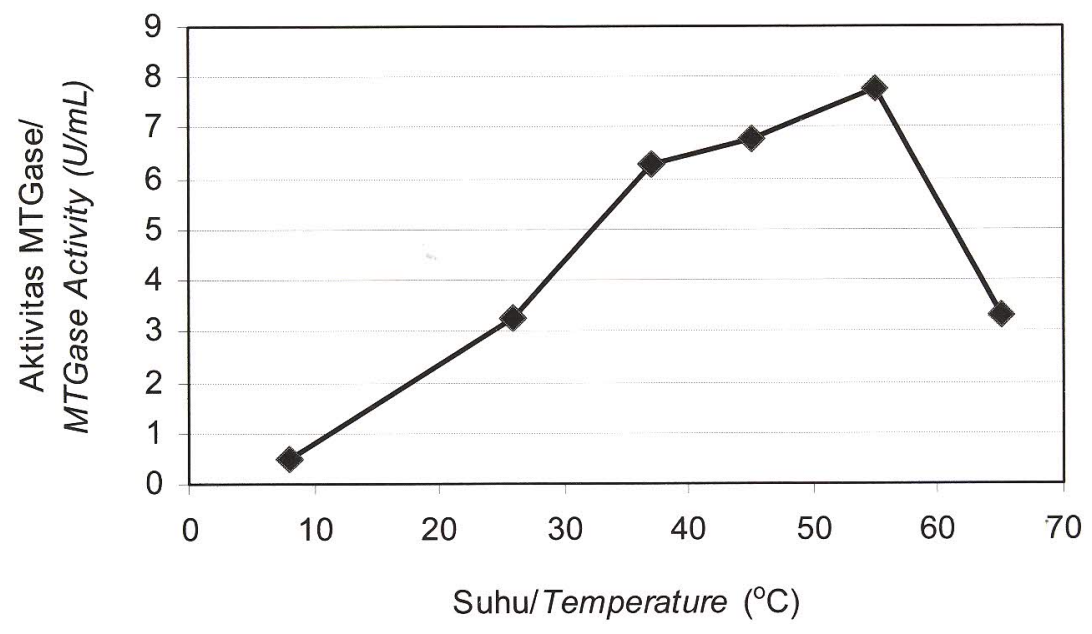

Gambar 3. Pengaruh suhu terhadap aktivitas MTGase dari S. ladakanum

Figure 3. Effect of temperature on MTGase activity of S. ladakanum.

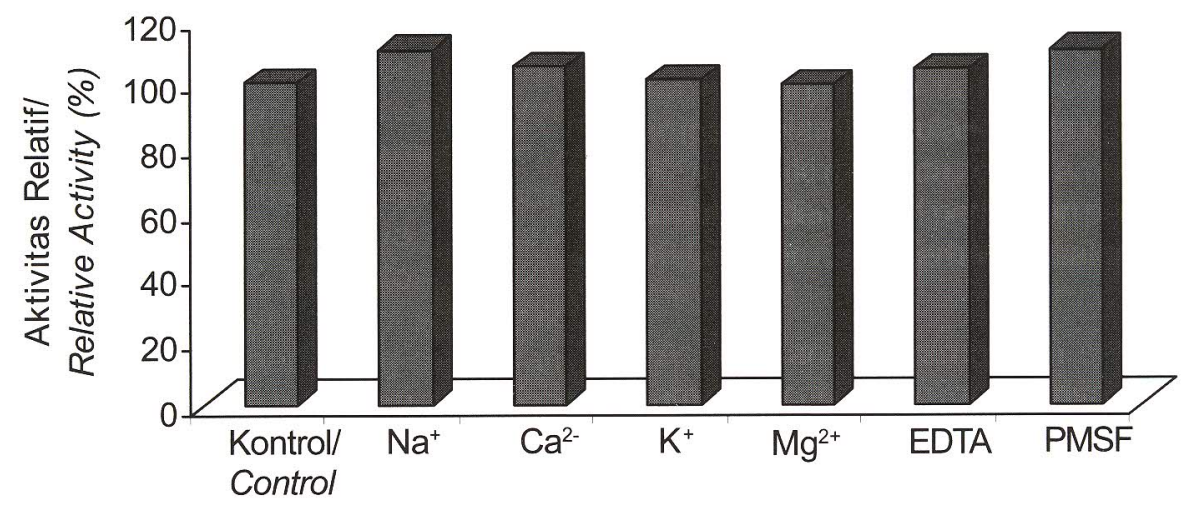

Ion Logam dan Inhibitor $1 \mathrm{mM} /$

Metal Ion and Inhibitor $1 \mathrm{mM}$

Gambar 4. Pengaruh ion logam dan inhibitor terhadap aktivitas enzim MTGase.

Figure 4. Effect of metal ions and inhibitors on MTGase activity.

terhadap aktivitasnya, demikian juga adanya EDTA dan PMSF yang biasanya bersifat sebagai inhibitor enzim, tidak memberikan pengaruh yang signifikan terhadap aktivitas enzim MTGase dari S. ladakanum ini (Gambar 4). Ando et al. (1989) melaporkan bahwa aktivitas MTGase dari Streptoverticillium S-8112 tidak dapat dihambat oleh EDTA maupun PMSF (phenylmethylsulfonylfluoride), namun MTGase ini dapat dihambat oleh PCMB (parachloromercuribenzoic acid), NEM ( $N$-ethyl-maleimide), dan MIA (monoiodoacetate).

\section{Aplikasi Enzim}

Aplikasi enzim pada suatu industri umumnya tidak menggunakan enzim murni, melainkan berupa enzim yang telah dipekatkan, cukup stabil, dan tidak mengandung sejumlah kontaminan. MTGase kasar yang dihasilkan dari penelitian ini memiliki aktivitas $30,57 \mathrm{U} / \mathrm{g}$, sedangkan TGase komersial memiliki aktivitas $67 \mathrm{U} / \mathrm{g}$; kedua jenis enzim tersebut diukur aktivitasnya berdasarkan metode kolorimetri (Grossowicz et al., 1950 dalam Ando, 1989).

Uji aplikasi MTGase pada daging lumat ikan mata goyang yang dilakukan mengikuti metode Ramirez et al. (2006) dengan menggunakan konsentrasi enzim $300 \mathrm{U} / \mathrm{kg}$ daging lumat menunjukkan bahwa perlakuan yang diberikan memberikan pengaruh nyata terhadap kekuatan gel $(p<0,05)$. Penambahan enzim TGase terbukti meningkatkan kekuatan gel produk restrukturisasi daging lumat ikan sekitar 2 kali lipat dari kontrol (hanya ditambahkan $\mathrm{NaCl}$ tanpa enzim) atau daging lumat ikan yang ditambahkan sodium kaseinat dan $\mathrm{NaCl}$ tanpa enzim. Pemberian sodium kaseinat bersama-sama dengan enzim MTGase tidak 


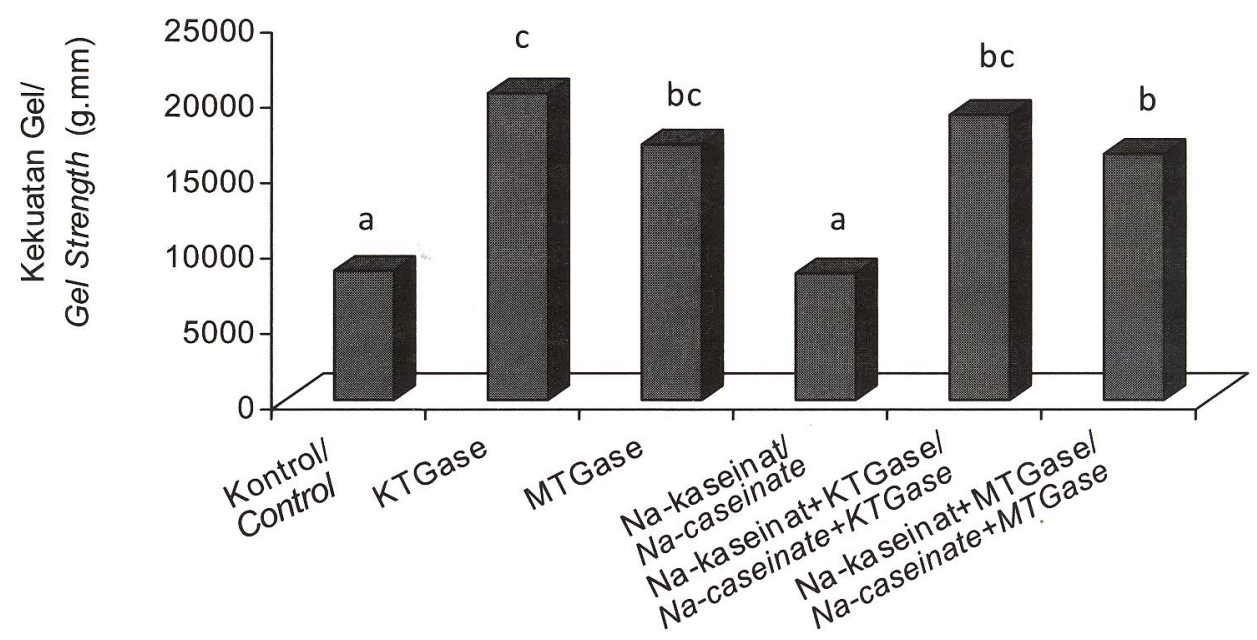

Gambar 5 . Pengaruh perlakuan TGase terhadap kekuatan gel daging lumat ikan mata goyang.

Figure 5. Effect of TGase on the gel strength of minced Priacanthus macracanthus.

berbeda nyata dengan penambahan MTGase saja, sehingga peningkatan kekuatan gel lebih disebabkan oleh adanya penambahan MTGase. Ramirez et al. (2006) menemukan bahwa penambahan TGase pada daging lumat dapat meningkatkan kekuatan gel, tetapi penambahan kasein dan konsentrat protein kedelai ternyata memiliki efek negatif terhadap elastisitas daging lumat. Dibandingkan dengan TGase komersial, TGase yang diproduksi dalam percobaan ini memiliki kemampuan meningkatkan gel yang relatif sama (tidak berbeda nyata) meskipun KTGase (komersial) memberikan kekuatan gel yang nilainya lebih tinggi. Hal ini kemungkinan disebabkan oleh komposisi KTGase yang mengandung garam $\mathrm{NaCl}$, maltodekstrin dan sodium kaseinat, sehingga perlakuan KTGase yang ditambah dengan garam $\mathrm{NaCl} 1 \%$ sebetulnya mengandung garam $\mathrm{NaCl}$ lebih dari $1 \%$.
Kamal et al. (2005) menemukan bahwa penggunaan garam $3 \%$ menghasilkan kekuatan gel tertinggi pada surimi dari Chorinemus lysan (queen fish). Menurut Seki et al. (1998) dalam Kamal et al. (2005) konsentrasi garam yang dibutuhkan untuk pembentukan gel kamaboko atau bahan seperti surimi adalah $2-3 \%$. Pembentukan gel ikan mulai terjadi pada saat penggilingan daging mentah dan akan meningkat dengan penambahan bahan aditif lainnya, seperti garam, konsentrat protein dan TGase. Aktomiosin (miosin dan aktin) sebagai komponen yang paling penting dalam pembentukan gel akan larut dalam larutan garam, membentuk sol (dispersi partikel padat dalam medium cair) yang sangat adhesif.

Perlakuan TGase tidak memberikan pengaruh yang nyata terhadap kekerasan (hardness) produk restrukturisasi $(p>0,05)$. Hal ini menunjukkan bahwa

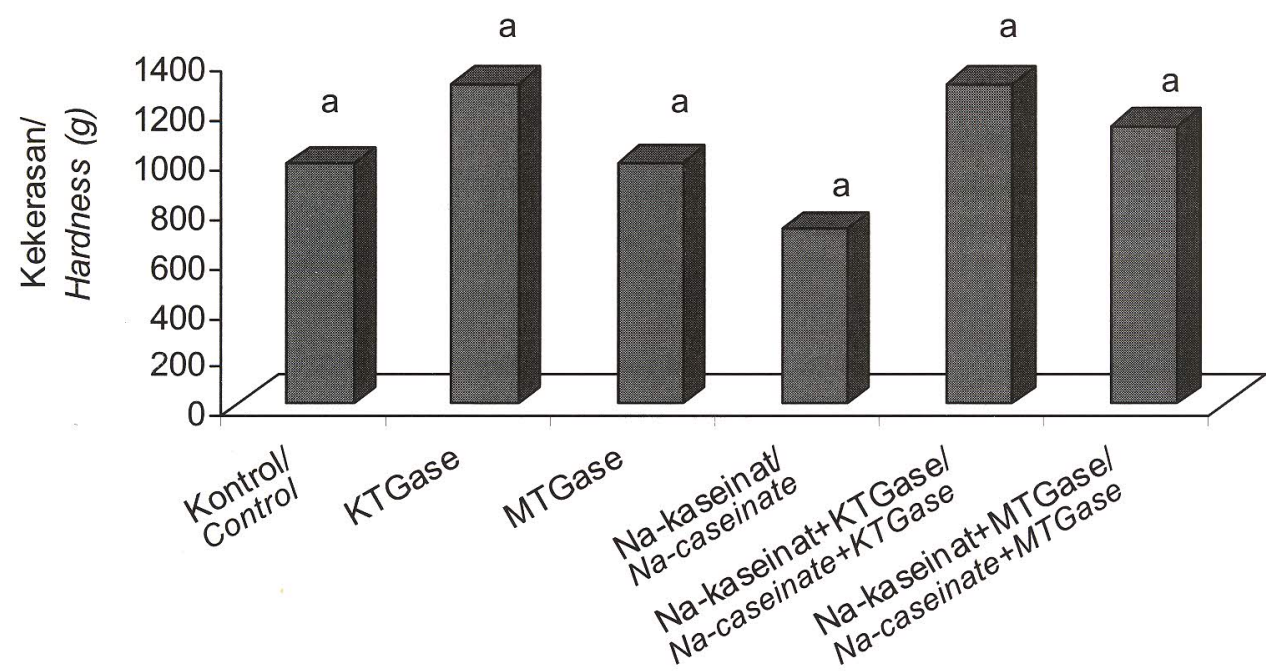

Gambar 6 . Pengaruh perlakuan TGase terhadap kekerasan gel daging lumat ikan mata goyang. Figure 6. Effect of TGase on hardness of minced Priacanthus macracanthus. 
penambahan KTGase, MTGase maupun sodium kaseinat tidak memberikan perbedaan yang signifikan dibandingkan dengan kontrol. Namun penambahan MTGase memberikan pengaruh yang nyata terhadap kekenyalan (springiness) dan kepadatan (cohesiveness) daging lumat $(p<0,05)$.

Kekenyalan dan kepadatan gel ikan menunjukkan pola yang serupa. Perlakuan penambahan MTGase dari S. ladakanum menghasilkan kekenyalan dan kepadatan gel ikan yang lebih tinggi dibandingkan penambahan KTGase (komersial). Umumnya enzim TGase mikroba yang diproduksi secara komersial berasal dari jenis Streptomyces mobaraensis (Yokoyama et al., 2004). Menurut Yokoyama et al. (2004), Streptomyces mobaraensis, sebelumnya dikenal dengan nama Streptoverticillium mobaraense. Jenis ini sama dengan Streptoverticillium ladakanum yang digunakan pada penelitian ini. Streptoverticillium ladakanum termasuk famili Streptomycetaceae. Bakteri ini memiliki nama lain yaitu Streptomyces mobaraense, Streptoverticillium mobaraense, Streptoverticillium ladhankaeanum, Streptomyces ladhankaeanus, Streptomyces ladakanum (Hanka et al., 1966 dalam Kristiana, 2009). Dengan demikian MTGase yang dihasilkan dari penelitian ini berasal dari jenis bakteri yang sama, meskipun diisolasi dari tempat yang berbeda.

Seperti halnya kekuatan gel pada Gambar 5, penambahan sodium kaseinat ke dalam daging lumat bersama-sama dengan KTGàse ataupun MTGase tidak meningkatkan kekenyalan (Gambar 7) dan kepadatan (Gambar 8) produk restrukturisasi yang dihasilkan dari perlakuan KTGase atau MTGase saja. Bahkan penambahan sodium kaseinat juga tidak

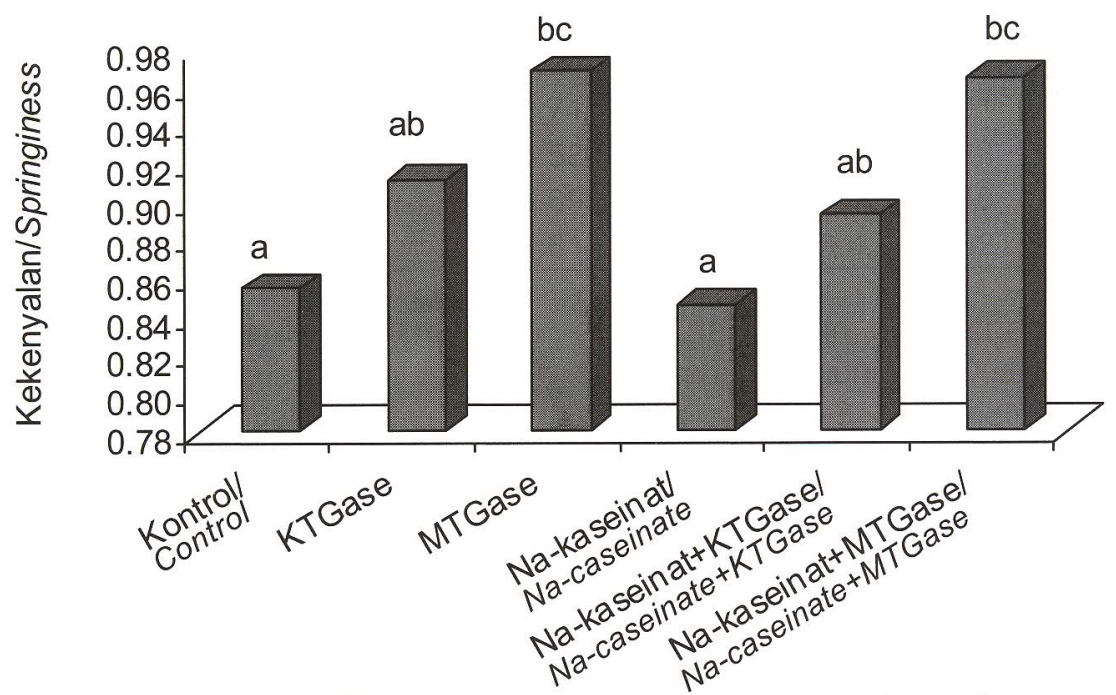

Gambar 7. Pengaruh perlakuan TGase terhadap kekenyalan daging lumat ikan mata goyang.

Figure 7. Effect of TGase on the springiness of minced Priacanthus macracanthus.

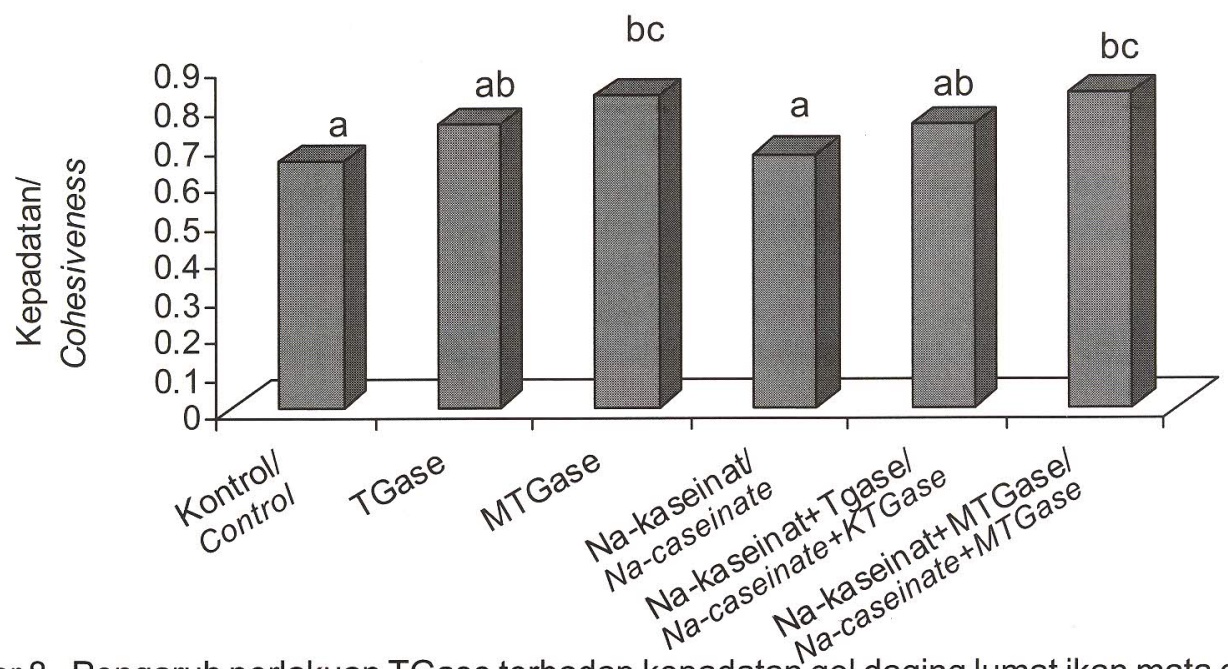

Gambar 8 . Pengaruh perlakuan TGase terhadap kepadatan gel daging lumat ikan mata goyang.

Figure 8. Effect of TGase on the cohesiveness of minced Priacanthus macracanthus. 
memberikan pengaruh terhadap kekuatan gel, kekenyalan dan kepadatan produk restrukturisasi dari perlakuan penambahan $\mathrm{NaCl}$ saja (kontrol). Runglerdkriangkrai et al. (2006) melaporkan bahwa penambahan sodium askorbat ke dalam daging lumat ikan yang mengandung TGase tidak berpengaruh nyata terhadap kekuatan gel bakso ikan yang dihasilkan, namun secara nyata meningkatkan kekuatan gel bakso tanpa perlakuan TGase (kontrol). Sodium askorbat yang semula dikenal sebagai bahan pengikat dan memiliki kemampuan meningkatkan kekuatan gel ternyata kurang efektif jika diberikan bersama-sama dengan TGase, serupa dengan sodium kaseinat. Sedangkan Pietrasik \& Jarmoluk (2003) melaporkan bahwa sodium kaseinat sampai dengan $2 \%$ dapat meningkatkan kekerasan tetapi tidak mampu meningkatkan kekenyalan atau kepadatan gel (produk daging lumat) daging babi.

\section{KESIMPULAN}

Berdasarkan hasil penelitian di atas dapat disimpulkan bahwa enzim transglutaminase mikroba (MTGase) yang diproduksi dari Streptoverticillium ladakanum menggunakan medium yang mengandung limbah cair tahu dan hidrolisat tapioka meningkat aktivitasnya sekitar 20 kali setelah dipekatkan menggunakan ultrafiltrasi cut off $10 \mathrm{kDa}$. Enzim ini bekerja optimum pada buffer Tris $\mathrm{HCl} 0,2 \mathrm{M} \mathrm{pH} 8$, suhu $55^{\circ} \mathrm{C}$. Adanya ion logam $\mathrm{K}, \mathrm{Na}, \mathrm{Ca}$, dan $\mathrm{Mg}$ serta inhibitor EDTA dan PMSF dengan konsentrasi $1 \mathrm{mM}$ relatif tidak berpengaruh terhadap aktivitas enzim.

Enzim MTGase ini memiliki kemampuan meningkatkan kekuatan produk restrukturisasi gel dari daging lumat ikan mata goyang (Priacanthus macracanthus) yang tidak kalah dengan enzim TGase komersial (Activa TG-BW-MH) dari PT. Ajinomoto.

\section{UCAPAN TERIMA KASIH}

Ucapan terima kasih diberikan kepada Sdri Fateha yang telah membantu dalam hal pengujian profil tekstur menggunakan Texture Analyzer.

\section{DAFTAR PUSTAKA}

Ando, H., Adachi, M., Umeda, K., Matsuura, A., Nonaka, M., Uchio, R., Tanaka, H., and Motoki, M. 1989. Purification and characterization of novel transglutaminase derived from microorganism. Agric. Biol. Chem. 53: 2613-2617.

Bollag, D.M. and Edelstein, S.J. 1991. Protein Methods. Wiley-Liss, New York. 230 pp

Fawzya, Y.N., Puruhita, T.K.A., Gunawan, dan Patantis, G. 2011'. Pengaruh garam dan enzim transglutaminase terhadap sifat fisik dan sensori daging restrukturisasi ikan mata goyang. Jurnal Pascapanen dan Bioteknologi Kelautan dan Perikanan. 6(1): 27-38.

Fawzya, Y.N., Pratitis, A., dan Patantis, G. 2011'b. Pengaruh penggunaan enzim transglutaminase terhadap kemampuan pembentukan gel daging lumat ikan tongkol (Euthynnus spp). Makalah dipresentasikan pada Seminar Masyarakat Pengolahan Hasil Perikanan Indonesia di Bogor, 6-7 Oktober 2011.

Gonçalves, A.A. and Passos, M.G. 2010. Restructured Fish Product from White Croacker (Micropogonias furnieri) Mince Using Microbial Transglutaminase. Brazilian Archives of Biology and Technology. (53)4: 987-995

Kamal, M., Hossain, M.I., Sakib, M.N., Shikha, F.H., Neazuddin, M., Bapary, M.A.J., and Islam, M.N. 2005. Effect of salt concentration and cryoprotectants on gel-forming ability of surimi prepared from queen fish (Chorinemus lysan) during frozen storage. Pak. J. Biol. Sci. 8: 793-797.

Kristiana, I. 2009. Optimasi komposisi media pertumbuhan Streptoverticillium ladakanum guna produksi transglutaminase dan aplikasinya pada daging lumat ikan mata goyang (Priacanthus macracanthus). Tesis. Program Studi Budidaya Perairan. Program Pascasarjana. Universitas Brawijaya. Malang. $81 \mathrm{pp}$.

Macedo, J.A., Sette, L.D., and Sato, H.H. 2007. Optimization of medium composition for transglutaminase production by a Brazilian soil Streptomyces $\mathrm{sp}$. Research article. Pontificia Universidad Católica de Valparaíso. http:// www.ejbiotechnology.info/content/vol10/issue4/full/ 10\%. Diakses pada tanggal 7 Juli 2011.

Mangunwidjaja, D. dan Suryani, A. 1994. Teknologi Bioproses. Penebar Swadaya. 394 pp.

Motoki, M. and Seguro, K. 1998. Transglutaminase and Its Use For Food Processing. Trends in Food Science \& Technology.

Lin, S.J., Hsieh, Y.F., Lai, L.A., Chao, M.L. and Chu, W.S 2008. Characterization and Large-Scale Production of Recombinant Streptoverticillium platensis transglutaminase. J. Ind. Microbiol. Biotechnol. 35: 981-990.

Pietrasik, Z. and Jarmoluk, A. 2003. Effect of sodium caseinate and $\kappa$-carrageenan on binding and textural properties of pork muscle gels enhanced by microbial transglutaminase addition. Food Research International. 36(3): 285-294.

Poedjiadi, A. 1994. Dasar-Dasar Biokimia. UI Press, Jakarta.

Ramirez, J. A., Angel, A.D., Velazquez, G., and Vazquez, M. 2006. Production of low-salt restructured fish products from Mexican flounder (Cyclopsetta chittendeni) using microbial transglutaminase or whey protein concentrate as binders. Eur Food Res Technol. 223: 341-345.

Ridwan, F.M. 2010. Produksi dan Karakterisasi Enzim Transglutaminase dari Streptoverticillium ladakanum dengan Media yang Disubstitusi Limbah Cair Surimi. Skripsi. Departemen Teknologi Hasil Perairan, Fakultas Perikanan dan IImu Kelautan. Institut Pertanian Bogor. 
Runglerdkriangkrai, J., Banlue, K., and Raksakulthai, N. 2006. High temperature tolerant fish protein gel using transglutaminase and sodium ascorbate. Kasetsart J. (Nat. Sci.) 40 (Suppl.): 84-90.

Suhartono, M.T. 1989. Enzim dan Bioteknologi. Dirjen Dikti, PAU Bioteknologi IPB, Bogor.

Suzuki, S., Izawa, Y., Kobayashi, K., Eto, Y., Yamanaka, S., Kubota, K., and Yokozeki, K. 2000. Purification and characterization of novel transglutaminase from Bacillus subtilis spores. Biosci. Biotechnol. Biochem. 64: 2344-2351.

Tellez-Luis, S.J., Ramirez, J.A., and Vazquez. 2004. Application in restructured fish products of transglutaminase obtained by Streptoverticillium ladakanum in media made from hydrolysates of sorghum straw. J. Food Sci. 69(1): FMS1-FMS5

Vacha, F., Noviki, I., Spickaz, J., and Podolai, M. 2006. Determination of the effect of microbial transglutaminase on technological properties of common carp (Cyprinus carpio L.) meat. Czech J. Anim. Sci. 51(12): 535-542.

Worratao, A. and Yongsawatdigul, J. 2005. Purification and characterization of transglutaminase from tropical Tilapia (Oreochromis niloticus). Food Chemistry. 93: 651-658.

Yokoyama, K., Nio, N., and Kikuchi, Y. 2004. Properties and applications of microbial transglutaminase. Appl Microbiol Biotechnol. 64(4):447-54.

Zilda, D.S., Patantis, G., Fawzya, Y.N., Kristiana, I., dan Nursyam, H. 2011. Pemanfaatan limbah cair tahu dan pati singkong untuk produksi enzim transglutaminase dari Streptoverticillium ladakanum sebagai bahan tambahan pembentuk gel ikan. Makalah dipresentasikan pada Seminar Nasional Pengolahan Produk dan Bioteknologi Kelautan dan Perikanan, tanggal 26 Juli 2011. 